\title{
CREATIVE WRITING AT THE UNIVERSITY: STUDENTS' PERCEPTIONS AND EXPECTATIONS
}

\author{
Nijolè Burkšaitienè \\ Mykolas Romeris University, \\ Institute of Philosophy and Humanities \\ Ateities str. 20, LT-08303 Vilnius, Lithuania \\ Tel.: (+370 5) 2714613 \\ E-mail: n.burksaitiene@mruni.eu
}

Received on 26 September, 2014; accepted on 30 October, 2014

doi:10.13165/SMS-14-6-3-13

\begin{abstract}
The present study is aimed at investigating students' perceptions of themselves in relation to creativity as well as their expectations from the course in creative writing in their university studies of English so that to support the process. The findings revealed that although half of study participants considered themselves to be creative, only a few of them were involved in creative writing. The study also resulted in the identification of students' expectations, including the expectations to better understand the nature of creativity and creative writing, gain specific knowledge about creative writers and the process of creative writing, practice creative writing, foster English as the language of their studies as well as learn more about themselves.

The findings suggest that to foster creativity in the new course in English, students' perceptions of themselves, the level of their awareness about creativity and creative writing as well as their expectations are important.

It is recommended that this study be extended to the investigation of students' experience of learning to become creative writers after they finish the course. This may lead to generalisations on how the creativity-favourable environment can be further enhanced.
\end{abstract}

Socialinių mokslų studijos / Societal Studies

(C) Mykolo Romerio universitetas, 2014

(C) Mykolas Romeris University, 2014
ISSN 2029-2244 (online)

http://www.mruni.eu/lt/mokslo_darbai/SMS/

http://www.mruni.eu/en/mokslo_darbai/SMS/ 
Keywords: creativity, creative writing, students' expectations, university studies of English.

\section{Introduction}

Relevance of the study and research problem. Creativity has been widely investigated by researchers from different perspectives and using different theoretical approaches. Torrance and Guilford, the pioneers in the field, considered divergent thinking to be central for creativity and created psychometric tests to measure it, whereas Sternberg preferred a confluence approach for the analysis of creativity ${ }^{1}$. The most recent research has been focused on different dimensions of creativity and ways to measure it, on the relationship between the perceived pleasantness of tasks and creative performance; besides, models/frameworks fostering creativityfavourable environments have been designed, as well as methods to stimulate creative thinking in classrooms (e.g., knowledge management and intelligent fast failure) have been studied ${ }^{2}$. Despite numerous studies, little is known about fostering creativity in learning English at tertiary level. The existing research on this subject has concentrated on the impact of self-reflection on developing students' creativity through portfolio-based learning and project-based learning ${ }^{3}$. However, students' perceptions of themselves in relation to creativity as well as their expectations in learning to become creative have been little analysed yet. The aim of the present study is to analyse creativity as perceived by students and to establish their expectations from the course in creative writing in the university studies of English. The research objectives include elaborating on the investment theory of creativity in relation to creative writing, describing the context of the present study and examining students' perceptions as well as providing recommendations on how to support the process. To carry out the research, descriptive statistics as well as qualitative methodology of content analysis were used.

1 Sternberg, R. J. The Nature of Creativity. Creativity Research Journal. 2006, 8(1): 87-98.

2 Piffer, D. Can Creativity be Measured? An Attempt to Clarify the Notion of Creativity and General Directions for Future Research. Thinking Skills and Creativity. 2012, 7: 258-264; Zenasni, F.; Lubart, T. Pleasantness of Tasks and Creative Performance. Thinking Skills and Creativity. 2011, 6: 49-56; Newton, D. P. Moods, Emotions and Creative Thinking: A Framework for Teaching. Thinking Skills and Creativity. 2013, 8: 34-44; Yu-chu, Y.; Yi-ling, Y.; Yu-Hua, Ch. From Knowledge Sharing to Knowledge Creation: A Blended Knowledge-Management Model for Improving University Students' Creativity. Thinking Skills and Creativity. 2012, 7: 245-257; Tahirsylaj, A. Stimulating Creativity and Innovation through Intelligent Fast Failure. Thinking Skills and Creativity. 2012, 7: 265-270.

3 Šliogeriene, J. Fostering Creativity through Self-reflection. Radoša Personiba [Creative Personality]. 2013, 11: 37-43; Burkšaitienè, N. Project-based Learning for the Enhancement of Self-regulated Learning and Creativity in a Course of ESP. Radoša Personiba [Creative Personality]. 2013, 11: 164-172. 


\section{Creativity and Creative Writing}

In the present study, the concept of creativity is derived from the investment theory. According to this theory, there are two factors that are particularly important for creativity, i.e., a personal decision and components of creativity, including intellectual ability, knowledge, styles of thinking, personality, motivation, and environment. From the investment theory perspective, creativity is not a simple sum of a personally acquired level of each of these components, but rather their confluence. This is because there exist thresholds for some of them, below which creativity is not possible (e.g., knowledge), on the other hand, one component (e.g., motivation) may partially compensate for the weakness of another component (e.g., the environment) or the interaction between two high level components (e.g., intelligence and motivation) may enhance creativity ${ }^{4}$.

According to Sternberg, intellectual ability combines three skills: the synthetic skill (to see problems in new ways and avoid conventional thinking), the analytic skill (to recognize valuable ideas to be pursued) and the practical-contextual skill (to know how to persuade others of the value of one's ideas), and if one of these skills is missing, creativity is likely to be hindered, therefore, a confluence of these skills is also required ${ }^{5}$.

The second component - knowledge - can both support creativity and interfere with it: on the one hand, one has to know one's field very well in order to create something new, on the other hand, past knowledge can result in "a closed perspective", therefore, one has to decide whether to use it ${ }^{6}$.

From the investment theory perspective, creativity is largely based on a personal decision to become creative, which leads to the assumption that creativity can be developed. Thus, one has to decide to think in new ways and on two levels - globally and locally (i.e., a legislative style of thinking is required for creativity), to have certain personality attributes (e.g., willingness to overcome difficulties, willingness to take sensible risks, willingness to tolerate ambiguity, and self-efficacy), to be motivated and make creativity part of one's life (i.e., intrinsic motivation is crucial) ${ }^{7}$.

Finally, to promote creativity, one needs a supportive environment, i.e., the environment which, within the context of education, is based on respectful relationships between teachers and learners, provides opportunities for peer collaboration as well as for constructive feedback, or creates autonomy-supporting surrounding for gifted individuals.

4 Sternberg, R. J., supra note 1.

5 Sternberg, R. J., supra note 1, p. 89.

6 Sternberg, R. J., supra note 1.

$7 \quad$ Ibid.

8 Davis, D.; Jindal-Snape, D.; Collier, C.; Digby, R.; Hay, P.; Howe, A. Creative Learning Environments in Education - A Systematic Literature Review. Thinking Skills and Creativity. 2013, 8: 80-91; Enko, J. Creative Writers' Experience of Self-determination: An Examination within the Grounded Theory Framework. Thinking Skills and Creativity. 2014, 14: 1-10. 
In the present study, creative writing is analysed in the light of the investment theory as a relatively new cultural activity which can be both taught and learnt ${ }^{9}$. Thus, it is hypothesized that each student can learn to become a creative writer if one decides to do so and if the environment supports their decision. To create such an environment, the teacher should be aware of what students already know about the nature of creativity and creative writing, about how to learn to become creative and what they expect to learn from the course in creative writing.

It is reported in literature that in higher education creative writing still remains a difficult and conflicted territory both at undergraduate and post-graduate levels, as it poses several challenges, including the question of clarity of assessment criteria, academic consensus on what kind of creative writing is good and, most importantly, how it can be fostered ${ }^{10}$.

In Lithuania, the existing research on this subject has been focused on developing students' creativity through self-reflection in portfolio-based learning and projectbased learning ${ }^{11}$, however, it did not cover students' perceptions of themselves in relation to creativity as well as their expectations from learning to become creative writers. The knowledge of this is important as it can help university teachers to design an environment stimulating this process. With this in mind, students' perceptions of themselves in relation to creativity and their expectations from a course in creative writing in their studies of English were studied. To carry out the research, descriptive statistics as well as qualitative methodology of content analysis were used.

\section{Method}

Participants. The sample of 18 students included 16 female and 2 male undergraduates between 20 and 21 who studied Translation and Editing at Mykolas Romeris University (Vilnius). None of them had taken a course in creative writing in English before.

Procedure. In the methodology of the investment theory of creativity, to foster creativity, it is important to consider the perspective of the participants, their readiness and willingness to decide to be creative, and the environment to support them. With this in mind, empirical data were collected through the questions designed so that to enable to obtain information about their perceptions and expectations. To establish if students considered themselves to be creative and in which areas as well as what their expectations from the new course were, they were asked to answer a close-

9 Nettle, D. The Evolution of Creative Writing. In: The Psychology of Creative Writing. S.B. Kaufmann, J.C. Kaufmann (eds.). Cambridge: CUP, 2009, p. 101-116; Sternberg, R. J., supra note 1 .

10 Boulter, A. Assessing the Criteria: An Argument for Creative Writing Theory. New Writing: The International Journal for the Practice and Theory of Creative Writing. 2004, 1(2): 134140; Curtis, A. Rethinking the Unconscious in Creative Writing Pedagogy. New Writing: The International Journal for the Practice and Theory of Creative Writing. 2009, 6(2): 105-116. 
ended question "Are you a creative person?" and two open-ended questions: "If you are creative, in what way?" and "What do you expect from the course in creative writing?". Descriptive statistics was used to establish the proportion of students who perceived themselves to be creative. Content analysis of students' responses was used to identify the areas in which students believed to be creative as well as expectations they had from the new course. Content analysis revealed repeated themes - areas of creativity as well as groups of expectations. The latter were further analysed, subgroups were identified and supplemented with samples of evidence.

\section{Results}

Descriptive statistics of students' responses to the close-ended question "Are you a creative person?" revealed that half of them $(\mathrm{n}=9$, or $50 \%)$ considered themselves to be creative. Content analysis of students' responses to the open-ended question "If you are creative, in what way?" revealed 4 areas of creativity they were involved in (Table 1).

Table 1. Areas of creativity

\begin{tabular}{|l|l|c|}
\hline \multicolumn{1}{|c|}{ Area } & \multicolumn{1}{|c|}{ Samples of evidence } & Instances \\
\hline $\begin{array}{l}\text { Generating } \\
\text { new/ } \\
\text { interesting } \\
\text { ideas }\end{array}$ & $\begin{array}{l}\text { "It's easy for me to generate new ideas [...], I'm good at } \\
\text { expressing myself"; "I always have some new ideas, }<\text { I }> \\
\text { love to create something new and interesting"; "I have } \\
\text { amazing ideas while choosing gifts for birthdays and } \\
\text { holidays"; "I'm full of ideas when I have an inspiration } \\
\text { or if I'm encouraged [...]" }\end{array}$ & 4 \\
\hline $\begin{array}{l}\text { Visual arts } \\
\text { and creati- } \\
\text { ve writing }\end{array}$ & $\begin{array}{l}\text { "I'm creative in art. Painting is my favourite way of } \\
\text { self-expression. I also express myself through writing. } \\
\text { I write short stories"; "I've always been creative as a } \\
\text { painter [...] I like painting. I paint or draw everywhere }\end{array}$ & 3 \\
\hline $\begin{array}{l}\text { - on human bodies, on paper, on the walls at home. } \\
\text { Sometimes I like to write a lot [...]"; "I like writing and } \\
\text { sometimes I draw or paint" }\end{array}$ & 1 \\
\hline $\begin{array}{l}\text { Creative } \\
\text { writing, } \\
\text { music and } \\
\text { organising } \\
\text { events }\end{array}$ & $\begin{array}{l}\text { "I write poetry, also I like to play the guitar and organise } \\
\text { some <cultural> events" }\end{array}$ & 1 \\
\hline $\begin{array}{l}\text { Organising } \\
\text { holidays }\end{array}$ & $\begin{array}{l}\text { "It depends on my mood. I sometimes go out with my } \\
\text { family or friends, organise holidays" }\end{array}$ & 1 \\
\hline
\end{tabular}


Area 1: generating new and/or interesting ideas. Four students considered themselves to be creative in generating new and interesting ideas: "I have amazing ideas choosing gifts for birthdays and holidays" and "It's easy for me to generate new ideas [...] I'm good at expressing myself" or "I always have some new ideas, $<$ I $>$ love to create something new and interesting". One student stated that encouragement supported her creativity: "I'm full of ideas when I have an inspiration or if I'm encouraged [...]".

Area 2: visual arts and creative writing. Content analysis revealed that three students perceived themselves to be creative in two areas of creativity: in visual arts and creative writing. They said: "I'm creative in arts. Painting is my favourite way of self-expression. I also express myself through writing. I write short stories" and "I've always been creative as a painter [...] I like painting. I paint or draw everywhere - on human bodies, on paper, on the walls at home. Sometimes I like to write a lot [...]" or "I like writing and sometimes I draw or paint".

Area 3: creative writing, music and organising events. One student noted that she was creative in three areas, including creative writing, playing a musical instrument and organising cultural events: "I write poetry, also I like to play the guitar and organise some <cultural> events".

Area 4: organising holidays. One student perceived herself to be creative in organising holidays. She said: "It depends on my mood. I sometimes go out with my family or friends, organise holidays".

To establish students' expectations from the course in creative writing, their responses to the open-ended question "What do you expect from the course in creative writing?" were analysed. Content analysis revealed that all study participants had more than one expectation, all of which were analysed and categorised. Thus, the study resulted in the identification of five groups of expectations, including raising one's understanding of creativity and creative writing, gaining specific knowledge, expectations to practice creative writing, to foster English as the language of their studies, and expectations to learn about oneself. Deeper analysis of the established groups (types) of students' expectations disclosed some sub-groups which are presented in Table 2.

Table 2. Students' expectations from the course in creative writing

\begin{tabular}{|l|l|l|l|}
\hline \multicolumn{1}{|c|}{ Group } & \multicolumn{1}{c|}{ Sub-group } & \multicolumn{1}{c|}{ Samples of evidence } & Instances \\
\hline $\begin{array}{l}\text { Raising one's } \\
\text { understanding } \\
\text { of creativity } \\
\text { and creative } \\
\text { writing }\end{array}$ & $\begin{array}{l}\text { Understanding } \\
\text { creativity / } \\
\text { learning } \\
\text { about } \\
\text { creativity }\end{array}$ & $\begin{array}{l}\text { "To understand what creativity is } \\
\text { and how to develop my creativity"; } \\
\text { "I'd like to better understand } \\
\text { creativity"; "To learn something } \\
\text { interesting about creativity and } \\
\text { become interested in creative } \\
\text { writing" }\end{array}$ & \\
\hline
\end{tabular}




\begin{tabular}{|c|c|c|c|}
\hline \multirow[t]{2}{*}{$\begin{array}{l}\text { Raising one's } \\
\text { understanding } \\
\text { of creativity } \\
\text { and creative } \\
\text { writing }\end{array}$} & $\begin{array}{l}\text { Learning about } \\
\text { the process } \\
\text { of creative } \\
\text { writing }\end{array}$ & $\begin{array}{l}\text { "To know better how to write a good } \\
\text { story"; "To know the subtleties of } \\
\text { writing"; "To learn from different } \\
\text { authors; learn about the structure } \\
\text { of texts"; "To understand how } \\
\text { writing starts; learn what you have } \\
\text { to know (and think about) before } \\
\text { writing and how to write some } \\
\text { stories" }\end{array}$ & \\
\hline & $\begin{array}{l}\text { Developing } \\
\text { one's creativity }\end{array}$ & $\begin{array}{l}\text { "To create something interesting"; } \\
\text { "To learn to use my imagination } \\
\text { and be more creative than I've ever } \\
\text { been"; "To become more creative" }\end{array}$ & \\
\hline \multirow{2}{*}{$\begin{array}{l}\text { Gaining } \\
\text { knowledge }\end{array}$} & $\begin{array}{l}\text { Learning } \\
\text { about creative } \\
\text { writers/ } \\
\text { creative } \\
\text { writing and } \\
\text { writers }\end{array}$ & $\begin{array}{l}\text { "To learn about writers I didn't } \\
\text { know before"; "To learn more } \\
\text { about creative writing and writers" }\end{array}$ & \multirow{2}{*}{3} \\
\hline & $\begin{array}{l}\text { Learning } \\
\text { about texts, } \\
\text { writing styles, } \\
\text { the language }\end{array}$ & $\begin{array}{l}\text { "To learn something new about } \\
\text { different types of texts and } \\
\text { literature"; "To expand my } \\
\text { knowledge about the writing } \\
\text { styles"; "To learn more about } \\
\text { English for creative writing" }\end{array}$ & \\
\hline $\begin{array}{l}\text { Practicing } \\
\text { creative } \\
\text { writing }\end{array}$ & $\begin{array}{l}\text { Practicing } \\
\text { creative } \\
\text { writing in } \\
\text { different } \\
\text { genres }\end{array}$ & $\begin{array}{l}\text { "I'd like to write some articles } \\
\text { and enjoy the process of writing"; } \\
\text { "To write something, maybe a } \\
\text { short story"; "To learn to write } \\
\text { in different genres"; "To write on } \\
\text { different topics: psychology, love, } \\
\text { studies, arts; write on my own topic } \\
\text { [...]" } \\
\text { "I expect to be able to write better } \\
\text { and improve English"; "To improve } \\
\text { my writing style"; "I expect to learn } \\
\text { to express ideas easier, using more } \\
\text { creative expressions [...]"; "To } \\
\text { learn how to express my ideas" }\end{array}$ & 4 \\
\hline
\end{tabular}




\begin{tabular}{|l|l|l|c|}
\hline $\begin{array}{l}\text { Fostering } \\
\text { English }\end{array}$ & $\begin{array}{l}\text { "I expect to learn more idioms } \\
\text { and new words"; "To broaden my } \\
\text { vocabulary [...]"; "To learn new } \\
\text { words" }\end{array}$ & 4 \\
\hline $\begin{array}{l}\text { Learning about } \\
\text { oneself }\end{array}$ & $\begin{array}{l}\text { "To find out if I am able to create- } \\
\text { write something interesting"; "To } \\
\text { know if I can be taught to write" }\end{array}$ & 2 \\
\hline
\end{tabular}

The results of the present study showed that half of participants $(n=9)$ expected to raise their understanding of the nature of creativity and creative writing. Three of them stated they expected to understand creativity and to learn about it, e.g., they wanted "To understand what creativity is and how to develop my creativity" and "I'd like to better understand creativity" or "To learn something interesting about creativity and become interested in creative writing". Another three students expected to learn about the process of creative writing, e.g., they wanted "To know better how to write a good story", "To know the subtleties of writing", "To learn from different authors; learn about the structure of texts" and "To understand how writing starts; learn what you have to know (and think about) before writing and how to write some stories". Three more students expected to develop their creativity and said that they wanted "To learn to use my imagination and be more creative than I've ever been", "To become more creative" and "To create something interesting".

The second group of expectations reflected five students' wish to gain some knowledge both about writers and creative texts, e.g., two students stated that they expected "To learn about writers I didn't know before" and "To learn more about creative writing and writers", and three students expected "To learn something new about different types of texts and literature", "To expand my knowledge about the writing styles" and "To learn more about English for creative writing".

The results of the study also showed that eight students expected to practice creative writing and improve their writing skills. Four of them expected to learn to write on different topics or in different genres, e.g., "To write on different topics: psychology, love, studies, arts; write on my own topic [...]", "To learn to write in different genres" and "I'd like to write some articles and enjoy the process of writing" or "To write something, maybe a short story". The other four students expected to improve their writing skills and learn to express ideas in writing: "I expect to be able to write better and improve English", "To improve my writing style" and "I expect to learn to express ideas easier, using more creative expressions [...]" or "To learn how to express my ideas".

The fourth group of expectations revealed that four students hoped to foster English as the language of their studies. They said: "I expect to learn more idioms and new words" and wanted "To broaden my vocabulary [...]" as well as "To learn new words" (stated by two students). 
Interestingly, the last group of expectations showed that 2 students expected to learn about themselves: "To find out if I am able to create-write something interesting" and "To know if I can be taught to write".

\section{Discussion and Conclusions}

The present research resulted in establishing students' perceptions of themselves in relation to creativity as well as identifying their expectations from the new course in creative writing in their university studies of English. The results showed that half of study participants (i.e., $n=9$ from the total $n=18$ ) perceived themselves to be creative, including two students who were amateur writers of poetry and short stories. On the other hand, it was established that only four students (from those who considered themselves to be creative) were involved in creative writing as well as in other areas of creativity (visual arts, music or organising events). The results also showed that the rest five students were creative in areas other than creative writing. These findings suggest that to foster creativity in the new course at the university, students' expectations are important.

The research illustrates that each study participant had more than one expectation from the course and that half of all study participants expected to better understand the nature of creativity and creative writing. An interesting finding of the study is that two study participants expected to learn something about themselves which is essential to learn to become creative. One of them wanted to learn if he has the abilities to create-write, the other one wanted to learn if he can be taught to do so. These finding are in line with Sternberg's ${ }^{12}$ arguments that to foster creativity, one should make a decision to do so, which is not possible if one is not fully aware of the nature of creativity.

The study resulted in the identification of four other groups of students' expectations, including their wish to gain theoretical knowledge about creative writers and the process of creative writing, practice creative writing in different genres and improve one's writing skills, as well as to foster English as the language of their studies. These findings suggest that university teachers should take students' expectations into consideration while designing the tasks for the course, which may lead to perceived pleasantness of the course. This reinforces the findings of Zenaski and Lubart ${ }^{13}$, who reported that student perceived pleasantness of the tasks influences their creative performance.

According to the investment theory, to foster creativity, a favourable environment is important ${ }^{14}$. The present research suggests that to design such an environment for a creative writing course, teachers should consider what students already know about

12 Sternberg, R. J., supra note, 1.

13 Zenasni, F.; Lubart, T., supra note 2.

14 Sternberg, R. J., supra note 1. 
creativity and creative writing, what their perceptions of themselves in relation to creativity are as well as what they expect from learning about creativity during their studies.

The study is innovative in that it increased our understanding of students' perceptions of themselves in relation to creativity and their expectations from the course in creative writing in their university studies of English. Future research should focus on students' experience of learning to become creative after they finish the course, which might lead to generalisations about the institution provided environment for creativity.

\section{References}

Boulter, A. Assessing the Criteria: An Argument for Creative Writing Theory. New Writing: The International Journal for the Practice and Theory of Creative Writing. 2004, 1(2): 134-140.

Burkšaitienè, N. Project-based Learning for the Enhancement of Self-regulated Learning and Creativity in a Course of ESP. Radoša Personiba [Creative Personality]. 2013, 11: 164-172.

Curtis, A. Rethinking the Unconscious in Creative Writing Pedagogy. New Writing: The International Journal for the Practice and Theory of Creative Writing. 2009, 6(2): 105-116.

Davis, D.; Jindal-Snape, D.; Collier, C.; Digby, R.; Hay, P.; Howe, A. Creative Learning Environments in Education - A Systematic Literature Review. Thinking Skills and Creativity. 2013, 8: 80-91.

Enko, J. Creative Writers' Experience of Self-determination: An Examination within the Grounded Theory Framework. Thinking Skills and Creativity. 2014, 14: 1-10.

Nettle, D. The Evolution of Creative Writing. In: The Psychology of Creative Writing. S.B. Kaufmann, J.C. Kaufmann (eds.). Cambridge: CUP, 2009, p. 101-116.
Piffer, D. Can Creativity be Measured? An Attempt to Clarify the Notion of Creativity and General Directions for Future Research. Thinking Skills and Creativity. 2012, 7: 258-264.

Newton, D. P. Moods, Emotions and Creative Thinking: A Framework for Teaching. Thinking Skills and Creativity. 2013, 8: 34-44.

Sternberg, R. J. The Nature of Creativity. Creativity Research Journal. 2006, 8(1): 87-98.

Šliogerienè, J. Fostering Creativity through Self-reflection. Radoša Personiba [Creative Personality]. 2013, 11: 37-43.

Tahirsylaj, A. Stimulating Creativity and Innovation through Intelligent Fast Failure. Thinking Skills and Creativity. 2012, 7: 265-270.

Yu-chu, Y.; Yi-ling, Y.; Yu-Hua, Ch. From Knowledge Sharing to Knowledge Creation: A Blended KnowledgeManagement Model for Improving University Students' Creativity. Thinking Skills and Creativity. 2012, 7: 245-257.

Zenasni, F.; Lubart, T. Pleasantness of Tasks and Creative Performance. Thinking Skills and Creativity. 2011, 6: 49-56. 


\title{
KŪRYBINIS RAŠYMAS UNIVERSITETE: STUDENTŲ POŽIŪRIAI IR KO TIKIMASI
}

\author{
Nijolè Burkšaitienè \\ Mykolo Romerio universitetas, Lietuva
}

\begin{abstract}
Santrauka. Šiuo tyrimu siekta išanalizuoti Mykolo Romerio universiteto Vertimo ir redagavimo bakalauro studiju II kurso studentų, anglų kalba studijuojančiu Kürybinio rašymo studiju dalyką, požiūrius i save, kaip i kūrybišką asmenį, bei nustatyti, ko yra tikimasi iš šio dalyko studijų tam, kad bütu galima numatyti, kokia studiju aplinka bütu palankiausia jų kūrybiškumui skatinti.

Studentu atsakymu analizès rezultatai rodo, kad nors 50 \% tyrime dalyvavusiu studentu, pradejusiu studijuoti Kürybinio rašymo studiju dalyką, save laiko kūrybiškais, tik mažiau nei puse iš ju savo kūrybiškumą sieja su kūrybiniu rašymu.

Tyrimo metu nustatyta, kad studentai iš studijų dalyko Kūrybinis rašymas tikisi suprasti kūrybiškumo ir kūrybinio rašymo prigimtị ir reikšmę, igyti specifinių žiniu apie kuriančius autorius ir kūrybinio rašymo procesą, praktiškai išbandyti jègas ịvairiuose kūrybinio rašymo žanruose, praturtinti anglų kalbos, kaip savo studiju kalbos, žodyna ir labiau pažinti save.

Tyrimo rezultatai leidžia teigti, kad siekiant sukurti kūrybiškuma skatinančią studiju aplinką studijuojant dalyką Kürybinis rašymas, svarbu atsižvelgti $i$ studentu požiūrius $\mathfrak{i}$ save kaip $\mathfrak{i}$ kūrybiškq asmenị, ị tai, kaip jie supranta kūrybiškumo ir kürybinio rašymo prigimtị ir reikšmę bei j̣ tai, ko jie tikisi iš dalyko Kürybinis rašymas studiju.

Rekomenduojama pasibaigus kursui išanalizuoti studentų kūrybinio rašymo dalyko studijavimo patirti. Tokio tyrimo rezultatai gali prisideti prie studiju aplinkos, skatinančios kūrybiškumą, tobulinimo.
\end{abstract}

Reikšminiai žodžiai: kūrybiškumas, kūrybinis rašymas, universitetinès anglų kalbos studijos, tai, ko tikimasi iš studiju.

Nijolė Burkšaitienė, Mykolo Romerio Universiteto Poltikos ir vadybos fakulteto Filosofijos ir humanistikos instituto profesorè. Mokslinių tyrimų kryptys: suaugusiųjų mokymasis, Specialiosios anglų kalbos studijos aukštajame moksle, inovatyvus mokymas ir studijų metodai, kūrybiškos studijos.

Nijolė Burkšaitienè, Mykolas Romeris University, Department of Politics and Management, Institute of Philosophy and Humanities, Professor. Research interests: adult learning, ESP studies in higher education, innovative teaching and study methods, creativity studies. 